\title{
The General Principles of International Criminal Law in the Criminal Code of the Republic of Kazakhstan
}

\author{
Sergey SAYAPIN* \\ KIMEP University, Kazakhstan \\ s.sayapin@kimep.kz
}

\begin{abstract}
International Criminal Law [ICL] contains a number of general principles, which form the foundations of and conditions for holding individuals criminally responsible for crimes under international law (genocide, crimes against humanity, war crimes, and the crime of aggression), and other crimes against the peace and security of mankind. Most general principles of ICL have been adequately implemented in the current (second) edition of the Criminal Code of the Republic of Kazakhstan. This paper assesses the quality of and identifies the lacunae in the implementation of Kazakhstan's Criminal Code, with a view to suggesting further improvements to this Code.
\end{abstract}

\section{GENERAL PRINCIPLES OF INTERNATIONAL CRIMINAL LAW}

As Werle and Jessberger usefully point out, general principles of international criminal law [ICL] have "become a focus of both practical relevance and scholarly interest". General principles of ICL are key system-building rules, which form the foundations of and conditions for criminal responsibility for the commission of crimes under international law. The core ICL principles, which are included in Part III of the Rome Statute of the International Criminal Court (hereinafter "the Rome Statute" or "the ICC Statute”, see Articles 22-33), are almost fully representative of customary international law. ${ }^{2}$ Since they reflect "a general practice accepted as law" 3 as far as the prosecution of crimes under international law is concerned, their inclusion in the current (second) edition of the Criminal Code of the Republic of Kazakhstan ${ }^{4}$ makes

Assistant Professor of International and Criminal Law, Director of the LLB in International Law programme at the School of Law, KIMEP University.

I. Gerhard WERLE and Florian JESSBERGER, Principles of International Criminal Law, 3rd ed. (Oxford: Oxford University Press, 20I4) at I 66.

2. The legal regulation of immunities under the ICC Statute probably constitutes the most significant departure from customary international law (cf. Part V below).

3. Cf. art. $38(\mathrm{I})$ (b) of the ICJ Statute.

4. The second edition of the Criminal Code of the Republic of Kazakhstan was adopted on 3 July 20I4, and entered into force on I January 20I 5. See the text of the Criminal Code (in Russian), online: <https:// online.zakon.kz/Document/?doc_id=3 I $575252>$ (last accessed 3 February 20I 8). 
sense, even though Kazakhstan is not a State Party to the Rome Statute and is not formally required to implement the Statute's rules. This paper considers the overall quality of implementation of general principles of ICL in the penal legislation of the Republic of Kazakhstan, and suggests some fine-tuning measures which could bring Kazakhstan's domestic penal law into fuller conformity with ICL.

\section{THE PRINCIPLE OF LEGALITY \\ (NULLUM CRIMEN / NULLA POENA SINE LEGE)}

The principle of legality is reflected in Articles $22^{5}$ and $23^{6}$ of the ICC Statute and Article 4 of the Criminal Code of the Republic of Kazakhstan. It provides that the notion of crimes under international law only includes acts (and, more rarely, omissions) whose criminality was explicitly formulated in a source of international law which applied at the time the act in question was committed, and for the commission of which individual criminal responsibility, associated with a sanction, was in place. Thus, the ICC has jurisdiction with respect to four categories of "core" crimes under international law (genocide, crimes against humanity, war crimes, and the crime of aggression), ${ }^{7}$ but in accordance with Article 22(3) of the Rome Statute, states are not precluded from characterizing any conduct as criminal under international law independently of the Statute. Kazakhstan's legislators did precisely this, and included the elements of "core" crimes under international law in Chapter 4 of the Criminal Code's Special Part ("Crimes against the peace and security of mankind"), along with some other crimes. The chapter includes, among others, crimes such as propaganda for war (Article I6I), the production, acquisition, or sale of weapons of mass destruction (Article I62), unlawful use of emblems protected by treaties (Article I67), ecocide (Article 169), mercenarism (Article 170), participation in armed conflicts abroad (Article I72), attacking internationally protected persons or organizations (Article I73), and the incitement of social, national, clan-based, racial, class-based, or religious discord (Article I74).

In turn, acts which are not explicitly defined as crimes under international law in the Criminal Code (for example, crimes against humanity) do not create criminal responsibility under the legislation of the Republic of Kazakhstan. In order to bring Kazakhstan's penal legislation into fuller conformity with applicable international law, the Kazakhstani legislature might, in the future, consider introducing criminal responsibility for crimes against humanity.

\section{NON-RETROACTIVITY RATIONE PERSONAE}

Article 24 of the ICC Statute lays down the principle of non-retroactivity ratione personae. ${ }^{8}$ Having regard to Article $\mathrm{I}_{5}$ of the International Covenant on Civil and

\footnotetext{
5. Cf. art. 22 of the ICC Statute ("Nullum crimen sine lege").

6. Cf. art. 23 of the ICC Statute ("Nulla poena sine lege").

7. Cf. art. 5 of the ICC Statute ("Crimes within the jurisdiction of the Court").

8. Cf. art. 24 of the ICC Statute ("Non-retroactivity ratione personae").
} 
Political Rights, ${ }^{9}$ this principle means that the rules of treaties and domestic criminal laws implementing ICL, which establish the criminality of certain acts, should not apply to acts which were committed before the respective treaties and/or domestic criminal laws were entered into force. At the same time, if a source of international or domestic criminal law is amended such that it improves the condition of the person being investigated, prosecuted, or convicted-for example, an act is decriminalized, or a less strict punishment is introduced—such a norm would also apply to acts committed in the past. This principle is embodied in Article 5 of the Criminal Code of the Republic of Kazakhstan, ${ }^{\text {IO }}$ and thus is part of the legislation of Kazakhstan.

\section{INDIVIDUAL CRIMINAL RESPONSIBILITY}

Article 25 of the ICC Statute ${ }^{\mathrm{II}}$ is fundamental to the modern system of international criminal justice. Article 25 of the ICC Statute explicitly allows only for individual criminal responsibility of natural persons in various forms of complicity. ${ }^{\mathrm{I} 2}$ This is unlike, for example, the Charters of the Nuremberg and Tokyo International Military Tribunals, which allowed for a collective dimension of criminal responsibility, particularly for membership in criminal organizations, or the case-law of the International Criminal Tribunals for the Former Yugoslavia and Rwanda, which produced the so-called "joint criminal enterprise" doctrine. ${ }^{\mathrm{I} 3}$ Thus, criminal responsibility of, for example, legal entities is excluded. Likewise, Article 25 is without prejudice to state responsibility under international law. ${ }^{\mathrm{I} 4}$ The provisions of the Republic of Kazakhstan's penal legislation on individual criminal responsibility ${ }^{\mathrm{I}}$ and complicity, ${ }^{\mathrm{I} 6}$ as well as criminal responsibility for inchoate offences ${ }^{\mathrm{I7}}$ presently reflect applicable ICL.

\section{EXCLUSION OF JURISDICTION OVER PERSONS UNDER I 8}

In accordance with Article 26 of the Rome Statute, the ICC has no jurisdiction over any person who was under the age of eighteen at the time of the alleged commission of a crime. In turn, in accordance with Article I 5 of the Criminal Code of the Republic of

9. For the text of the Covenant, see online: <http://www.ohchr.org/en/professionalinterest/pages/ccpr. aspx> (last accessed 4 February 20I8).

Iо. Cf. art. 5 of the Criminal Code of the Republic of Kazakhstan ("Temporal application of the penal law"): "The criminality and punishability of an act shall be determined by the law, which applied at the time of commission of that act [...].”

I I. Cf. art. 25 of the ICC Statute ("Individual criminal responsibility").

I2. Ibid., at 198-9, 205-20. See also Kai AMBOS, Treatise on International Criminal Law, Volume I: Foundations and General Part (Oxford: Oxford University Press, 2013) at I44-79.

I3. See Werle and Jessberger, supra note I at 200-4. See also Ambos, supra note I2 at I23-7.

I4. On the responsibility of states, see generally James CRAWFORD, State Responsibility: The General Part (Cambridge: Cambridge University Press, 2013).

I 5. Cf. art. I5(I) of the Criminal Code of the Republic of Kazakhstan ("Criminally liable individuals"): "A sane natural person having attained the age of sixteen years by the time of committing a criminal offence shall be criminally liable."

I6. Cf. arts. 27-3 I of the Criminal Code of the Republic of Kazakhstan.

I7. Cf. art. 24 of the Criminal Code of the Republic of Kazakhstan. See also Ambos, supra note I 2 at $233-52$. 
Kazakhstan, the age of criminal responsibility for the commission of crimes against the peace and security of mankind is sixteen. The same Article provides for criminal responsibility of persons who attained the age of fourteen at the time the crime was committed under Article 173 of the Criminal Code (attacking internationally protected persons or organizations). Hence, the penal legislation of Kazakhstan applies to a broader range of potential perpetrators of crimes under international law than international law itself does. At the same time, it appears that the age of criminal responsibility could be reduced to fourteen years for some other crimes against the peace and security of mankind, such as war crimes (Articles $163-165$ of the Criminal Code) and genocide (Article I68).

\section{IRRELEVANCE OF OFFICIAL CAPACITY}

Article 27 of the Rome Statute ${ }^{\mathrm{I} 8}$ provides that persons in whose respect the ICC exercises jurisdiction may not invoke personal or functional immunities, ${ }^{\text {I9 }}$ which they may possess under national or international law, as a ground for exempting such persons from criminal responsibility or for a reduction of sentence. This is because personal or functional immunities are granted to a state's highest officials and diplomats not for their own benefit but in order to facilitate their state's functions in domestic and foreign policy, and the commission of crimes under international law is not a normal function of states. ${ }^{20}$ In the course of implementing Article 27 in their respective constitutional, penal (substantive and procedural), and administrative laws, State Parties to the Rome Statute are obliged to repeal the immunities of heads of state and government, members of Parliaments, heads of ministries and agencies, judges, diplomats, and other officials. This is so as to facilitate their prosecution in domestic systems of criminal justice. It should be noted that the existence of an immunity should not prevent the prosecution of an official by an international criminal court: " $[\mathrm{I}] \mathrm{n}$ the case of the International Criminal Court, this is true even when the perpetrator derives his or her immunity from a non-state party."2I

Since the Republic of Kazakhstan is not a party to the Rome Statute, it follows customary international law, and not the Statute, as far as the regulation of immunities from criminal prosecution is concerned. Under customary international law, diplomatic agents as well as heads of state and government, and ministers of foreign affairs enjoy immunity from criminal prosecution by national (domestic or foreign) courts. ${ }^{22}$ The order of holding such officials criminally responsible is regulated by treaties of the Republic of Kazakhstan. ${ }^{23}$

\footnotetext{
I 8. Cf. art. 27 of the ICC Statute ("Irrelevance of official capacity").

I9. See Werle and Jessberger, supra note I at 270-3. See also Ambos, supra note I 2 at 406-Io.

20. See Werle and Jessberger, supra note I at 274.

2I. Ibid., at 279.

22. See Antonio CASSESE, Paola GAETA, Laurel BAIG, Mary FAN, Christopher GOSNELL, and Alex WHITING, Cassese's International Criminal Law, 3rd ed. (Oxford: Oxford University Press, 20I3) at $240-8$.

23. Sее И. Ш. Борчашвили, Комментарий к Уголовному кодексу Республики Казахстан: Общая часть, том I (Алматы, Жеті жарғы, 201 5), стр. І І 2-I4.
} 


\section{RESPONSIBILITY OF COMMANDERS AND OTHER SUPERIORS}

Article 28 of the ICC Statute ${ }^{24}$ establishes the criminal responsibility of military commanders or civilian superiors for the commission of crimes under international law by their subordinates if an individual commander or superior knew or should have known that his or her subordinates were committing or about to commit such crimes, and failed to take all necessary and reasonable measures within his or her power to prevent or repress their commission or to submit the matter to the competent authorities for investigation and prosecution. To a certain extent, the legal relationship of criminal responsibility of commanders or other superiors is covered by the elements of a crime provided for in the first paragraph of Article 166 of the Criminal Code, ${ }^{25}$ but this crime is circumstantially related to armed conflicts, and the criminal responsibility of a commander or another superior arises under this Article only if his or her subordinate commits a war crime but not another crime under international law. Hence, it would make sense to amend this Article such that it establishes the criminal responsibility of commanders or other superiors for negligence or issuing orders to commit other crimes against the peace and security of mankind (also see Part XII below).

\section{NON-APPLICABILITY OF STATUTE OF LIMITATIONS}

In accordance with Article 29 of the ICC Statute, the crimes within the jurisdiction of the Court shall not be subject to any statute of limitations. Overall, this rule reflects the provisions of the Convention on the Non-Applicability of Statutory Limitations to War Crimes and Crimes against Humanity of 26 November 1968, and relevant rules of customary international law. It should be noted that the I968 Convention is without prejudice to the non-applicability of statutory limitations to the crimes of genocide and aggression. For the purposes of the ICC, the statute of limitations does not apply to all four categories of crimes under international law which the ICC has jurisdiction over. With respect to the crime of aggression, the question of limitation periods would only matter after the activation of the ICC jurisdiction. ${ }^{26}$ In full compliance with international law, the penal legislation of the Republic of Kazakhstan does not provide for statutory limitations with respect to crimes against the peace and security of mankind. ${ }^{27}$

24. Cf. art. 28 of the ICC Statute ("Responsibility of commanders and other superiors").

25. Cf. art. I66(I) of the Criminal Code of the Republic of Kazakhstan ("Negligence or issuance of a criminal order during an armed conflict"): "Deliberate failure, during an armed conflict, on the part of a superior or official acting within [his or her] competence to take all feasible measures to prevent preparation for, or repress the commission by, a subordinate of criminal violations of the laws and customs of war or rules of international humanitarian law [...]."

26. On this matter, see for example N. STÜRCHLER, "The Activation of the Crime of Aggression in Perspective", online: <https://www.ejiltalk.org/the-activation-of-the-crime-of-aggression-in-perspective/> (last accessed 4 February 20I8).

27. See the sixth paragraph of art. 7I of the Criminal Code of the Republic of Kazakhstan ("Releasing from criminal responsibility by virtue of lapse of a statute of limitations"). 


\section{MENTAL ELEMENT}

A literal interpretation of Article 30 of the Rome Statute ${ }^{28}$ suggests that the mental element of crimes under international law, which are within the ICC jurisdiction, is direct intent. ${ }^{29}$ However, it follows from the case-law of the International Criminal Tribunal for the Former Yugoslavia-which certainly has an impact on the ICC case-law-that in some cases, criminal responsibility, for example for the commission of war crimes or crimes against humanity, might involve indirect intent. ${ }^{30}$ In turn, the crimes of genocide or aggression can only be committed with direct intent. In the case of the crime of genocide, the intent requirement is special-it is directed at the destruction, in whole or in part, of a national, ethnic, racial, or religious group as such. In the case of the crime of aggression, the intent of a special subject (a high-ranking official with political and/or military authority in a state) is directed at the use by that state of military force against another state, in violation of international law. Hence, in the context of the crime of aggression, indirect intent and negligence do not fulfil the mental element. ${ }^{3 \mathrm{I}}$

\section{GROUNDS FOR EXCLUDING CRIMINAL RESPONSIBILITY}

The grounds for excluding criminal responsibility, which are listed in Article $3 \mathrm{I}$ of the Rome Statute, ${ }^{32}$ are by and large reflected in the penal legislation of the Republic of Kazakhstan, ${ }^{33}$ which attests to their customary character. Such grounds as mental disease of defect, self-defence and defence of others, or duress, are common to most domestic legal systems and raise no questions. On the other hand, in accordance with Article 54(I 2 ) of Kazakhstan's Criminal Code, intoxication by alcohol, drugs, or other toxic substances is, as a rule, regarded as a circumstance aggravating criminal responsibility and punishment. According to the second sentence of the same provision, in exceptional cases, a court might not view such circumstances as aggravating, having regard to the character of the criminal offence in question.

It should be noted further that the list of grounds for excluding criminal responsibility in Article 3 I of the Statute is not exhaustive, and the ICC may also recognize other circumstances, such as mistakes (see Part XI below), as sufficient to extinguish a person's criminal responsibility, where such grounds are derived from applicable law as set out in Article $2 \mathrm{I}$ of the Statute.

28. Cf. art. 30 of the ICC Statute ("Mental element").

29. Cf. art. 20(2) of the Criminal Code of the Republic of Kazakhstan ("Criminal offence committed with intent"): "A criminal offence is committed with a direct intent, if the perpetrator is aware of the social danger of [his or her] act (omission), foresees a feasibility or inevitability of socially dangerous consequences, and desires their onset."

30. Cf. art. 20(3) of the Criminal Code of the Republic of Kazakhstan: "A criminal offence is committed with an indirect intent, if the perpetrator is aware of the social danger of [his or her] act (omission), foresees a feasibility of socially dangerous consequences, or treats them indifferently."

3I. See Sergey SAYAPIN, The Crime of Aggression in International Criminal Law: Historical Development, Comparative Analysis and Present State (The Hague: T. M. C. Asser Press/Springer, 20I4) at 236-4I, 293.

32. Cf. art. 3 I of the ICC Statute ("Grounds for excluding criminal responsibility"). See also Ambos, supra note $\mathrm{I} 2$ at $30 \mathrm{I}-93$.

33. Cf. arts. 65-7I of the Criminal Code of the Republic of Kazakhstan. 


\section{MISTAKE OF FACT OR MISTAKE OF LAW}

In accordance with Article 32 of the ICC Statute, ${ }^{34}$ a mistake of fact or law may be a ground for excluding criminal responsibility if it negates the mental element required by the crime in question. In this sense, Article 32 is meaningfully related to Article 3 I of the Statute (see Part IX above). A mistake of fact is an erroneous perception by the perpetrator of a crime regarding facts which constitute the material elements (actus reus) of the crime: 35 "This is the case, for example, if the perpetrator shoots at a Red Cross vehicle because he or she assumes, due to bad visibility, that this is an enemy tank." 36

One may assume indeed that the perpetrator would not shoot at a Red Cross vehicle, knowing that it was protected by international humanitarian law, if he had discerned that the vehicle was not an enemy tank but a humanitarian transport.

In turn, a mistake of law is a confusion on the part of the perpetrator of a crime regarding a legal qualification of the material elements of an act or omission. An irrelevant mistake of law is not a ground for extinguishing an individual's criminal responsibility because it does not negate the mental element required by the crime-in such cases, "only mitigation of punishment is possible". ${ }^{37}$ In contrast, a relevant mistake of law does negate the mental element required by the crime, and hence may constitute a ground for extinguishing an individual's criminal responsibility:

A relevant mistake of law is present, for example, if a perpetrator holding a trial of prisoner of war considers an objectively insufficient hearing of the defendant to be sufficient. In such a case, the perpetrator is not responsible for a war crime under Article $8(2)(\mathrm{a})(\mathrm{vi})$ of the ICC Statute. ${ }^{38}$

The penal legislation of the Republic of Kazakhstan does not contain explicit provisions on mistakes of fact or law. However, this does not mean that the concepts are unknown to the Kazakhstani doctrine of criminal law. Both concepts are implicit in the Criminal Code's provisions on the mental element of crimes (cf. Part IX above), and, in practical terms, might have an impact on the qualification of crimes (especially war crimes) and sentencing.

\section{SUPERIOR ORDERS AND PRESCRIPTION OF LAW}

Article 33 of the ICC Statute ${ }^{39}$ introduces criminal responsibility for crimes under international law where such crimes are committed pursuant to an order of a military commander or a civilian superior. This provision of ICL is required to prevent impunity, since defendants in international criminal trials may attempt to claim that they committed the acts in question pursuant to superior orders, which they were compelled to obey by virtue of legal or factual hierarchies. ${ }^{40}$ Under Article 33 , in order

\footnotetext{
34. Cf. art. 32 of the ICC Statute ("Mistake of fact or mistake of law”).

35. See Werle and Jessberger, supra note I at 246.

36. Ibid. (footnotes omitted).

37. Ibid., at 247 .

38. Ibid., at 248 (footnotes omitted).

39. Cf. art. 33 of the ICC Statute ("Superior orders and prescription of law").

40. See Werle and Jessberger, supra note I at 248-253.
} 
for a person who committed a crime under international law pursuant to a superior order to avoid criminal responsibility, all three circumstances listed in Article 33(I) must be present. It is thus presumed that orders to commit genocide or crimes against humanity are manifestly unlawful-that is, the criminal character of these acts is so self-evident that no justification by reference to a superior order may be accepted.

In turn, orders to commit war crimes or a crime of aggression are not manifestly unlawful, in accordance with Article 33(2) of the Rome Statute. This is related, above all, to the technical complexity of the rules of international humanitarian and criminal law, and of the law of international security, which regulates the respective primary legal relations. One should not expect non-experts to be professionally competent in the relevant areas of law-most potential (military and civilian) perpetrators of war crimes and the crime of aggression are not law experts. Providing legal advice to military commanders and civilian superiors on matters of international and domestic law is a task for competent legal advisers. ${ }^{4 \mathrm{I}}$

However, the penal legislation of the Republic of Kazakhstan categorizes orders to commit war crimes provided for in Articles I63-I65 of the Criminal Code as manifestly unlawful, and the second paragraph of Article I 66 establishes the criminal responsibility of a superior or official who issues such an unlawful order. It may hence be inferred that members of the armed forces of the Republic of Kazakhstan who refuse to comply with orders to commit war crimes should not be held criminally responsible under Article 437 of the Criminal Code. ${ }^{42}$ As far as orders to commit other crimes against the peace and security of mankind are concerned, they must be covered by Article 38 of the Criminal Code. ${ }^{43}$ It appears that the criminal responsibility of perpetrators depends on whether they actually comply with an order to commit a crime against the peace and security of mankind, the level of their legal conscience, and whether the court considers the order to be manifestly unlawful.

\section{CONCLUSION}

The second edition of the Criminal Code of the Republic of Kazakhstan has incorporated most of the general principles of ICL. Further improvements could be made in order to bring the Code into fuller conformity with ICL, especially as far as the notion of crimes against humanity is concerned. The current extent of implementation of general ICL principles in domestic penal law and procedure enables Kazakhstan's

4I. Cf. art. 82 of the First Additional Protocol of 8 June I 977 to the 1949 Geneva Conventions.

42. Cf. art. 437 (I) of the Criminal Code of the Republic of Kazakhstan ("Disobedience or another noncompliance with an order"): "Disobedience, that is, refusal to comply with a superior's order, as well as another deliberate failure to comply, on the part of a subordinate, with a superior's order issued in due course, which have caused a significant harm to the interests of service [...]."

43. Cf. art. 38 of the Criminal Code of the Republic of Kazakhstan ("Compliance with an order or instruction"): “I. Causing harm to interests protected by the present Code shall not be a criminal offence, if a perpetrator acts in pursuance of an order or instruction, which is mandatory for him. Criminal responsibility for causing such harm shall be borne by the person who issues an unlawful order or instruction. 2. A person who commits a deliberate criminal offence in pursuance of a manifestly unlawful order or instruction shall bear criminal responsibility on general grounds. Non-compliance with a manifestly unlawful order or instruction shall exclude criminal responsibility." 
horizontal co-operation with other states in combating transnational crimes. To date, Kazakhstan has had no experience of prosecuting individuals for crimes against the peace and security of mankind, except for participation in armed conflicts abroad and for the incitement of social, national, clan-based, racial, class-based, or religious discord. If Kazakhstan ever has to prosecute someone for crimes under international law stricto sensu, its law enforcement officials and judges would probably require more training on ICL, as far as general principles and the elements of crimes are concerned. Furthermore, if Kazakhstan ever accedes to the ICC Statute, it would certainly have to amend its (substantive and procedural) penal legislation to enable vertical co-operation with the ICC in the prosecution of crimes under international law, especially with respect to reducing the protective effects of granting immunity to particular individuals. 